\title{
Jumlah Total Mikroba Susu Kedelai (Glycine max) Dengan Penambahan Sari Jahe Merah Selama Penyimpanan
}

\author{
Centhya Victorin Maitimu'; Lanny Wattimena ${ }^{2}$ \\ ${ }^{1}$ Universitas Victory Sorong \\ victorin.chya@gmail.com
}

\begin{abstract}
ABSTRAK
Susu kedelai merupakan minuman kesehatan bernilai gizi tinggi dengan kandungan protein utama yang terdapat didalamnya. Susu kedelai segar telah diproduksi masyarakat Desa Layeni Kabupaten Maluku Tengah sejak lama dengan menggunakan teknik produksi secara konvensional. Walaupun memiliki cita rasa yang tidak berbeda dengan produk olahan pabrik, akan tetapi produk susu kedelai yang diproduksi masyarakat Desa Layani rentan terkontaminasi mikroba karena proses pengolahannya kurang steril dan tidak menggunakan pengawet buatan dalam pengolahannya. Dengan cara konvensional masyarakat Desa Layeni mendayagunakan zat tambahan alami berupa jahe merah yang diekstrak untuk meningkatkan daya simpan susu kedelai sekaligus berfungsi sebagai zat anti mikroba guna menekan laju pertumbuhan mikroba. Tujuan penelitian ini adalah untuk mengetahui jumlah total mikroba susu kedelai (Glycine max) hasil olahan masyarakat Desa Layeni Kecamatan Teon Nila Serua Kabupaten Maluku Tengah dengan penambahan sari jahe merah (zingiber officinale var. rubrum) selama penyimpanan. Jenis penelitian yang digunakan adalah penelitian eksperimen laboratorium, dengan tingkatan konsentrasi sari jahe merah yaitu $0 \%, 0,5 \%, 1 \%$ dan $1,5 \%$. Hasil penelitian menunjukkan bahwa jumlah total mikroba susu kedelai terendah terdapat pada kosentrasi $1,5 \%$ tanpa penyimpanan $(0$ jam $)$ yaitu $\left(3,4 \times 10^{4}\right.$ koloni/ml) sedangkan jumlah total mikroba tertinggi terdapat pada konsentrasi sari jahe merah $0 \%$ penyimpanan 24 jam yaitu $\left(9,5 \times 10^{7} \mathrm{koloni} / \mathrm{ml}\right)$. Menurut Standard Nasional Indonesia (SNI) No.06.8-7388-2009 persyaratan cemaran mikroba pada produk sari kedelai yaitu mengandung total mikroba maksimal $5 \times 10^{4}$ koloni $/ \mathrm{ml}$, maka dapat disimpulkan bahwa penambahan kosentrasi $1,5 \%$ sari jahe merah (Zingiber officinale var. Rubrum) dapat meningkatkan daya simpan susu kedelai selama 6 jam dengan total mikroba 4,3 x 10 $\mathrm{koloni} / \mathrm{ml}$.
\end{abstract}

Kata Kunci : Kedelai, Susu Kedelai, Sari Jahe Merah, Total Mikroba

\section{PENDAHULUAN}

Kedelai merupakan salah satu komoditas tanaman pangan nabati yang cukup diminati oleh masyarakat, juga memiliki peran penting dalam perekonomian negara di masa yang akan datang. Proses pengolahan kedelai menjadi berbagai produk makanan pada umumnya menggunakan proses yang sederhana, dengan alat-alat yang bisa dipakai di rumah tangga. Susu kedelai merupakan salah satu produk hasil 
diversifikasi pangan yang bertujuan untuk memberikan alternatif pilihan produk yang beragam pada konsumen (Astawan, 2009).

Susu kedelai memiliki nilai gizi yang jauh lebih baik dibandingkan dengan susu sapi dan sangat baik digunakan sebagai pengganti susu sapi bagi anak-anak yang menderita intoleransi laktosa. Susu kedelai merupakan minuman yang bergizi tinggi, terutama karena kandungan proteinnya (sebesar 3,5-4,0\%), selain itu, susu kedelai juga mengandung lemak, karbohidrat, kalsium, fosfor, zat besi, provitamin A, vitamin B kompleks (kecuali B12), dan air. Susu kedelai segar yang diproduksi secara konvensional oleh masyarakat Desa Layeni Kecamatan Teon Nila Serua Kabupaten Maluku Tengah memiliki cita rasa dan kandungan nilai gizi baik. Kelemahannya adalah susu kedelai rumahan rentan terkontaminasi mikroba karena proses pengolahannya yang kurang steril dan tidak menggunakan bahan pengawet buatan. Hal ini mengakibatkan daya simpan susu kedelai tradisional relatif pendek dan tidak memenuhi kriteria susu segar yang baik.

Proses pengolahan susu kedelai segar dengan sterilisasi sederhana dan pasteurisasi dapat mempertahankan kualitasnya sampai 48 jam, dengan penyimpanan pada suhu kamar. Lama pemanasan, penyimpanan, dan jenis pengemasan berpengaruh terhadap angka keasaman yang menyebabkan susu asam, memiliki rasa langu, dan tidak awet (Resnawati, 2006).

Zat tambahan makanan dikategorikan menjadi zat tambahan alami seperti jahe, dalam pengolahan berfungsi untuk meningkatkan daya simpan berfungsi mengawetkan dengan tujuan untuk menghambat atau menghentikan aktivitas mikroba seperti bakteri, kapang dan khamir. Jahe merupakan salah satu zat tambah makanan yang memiliki kemampuan mempertahankan kualitas pangan yaitu sebagai antimikroba. Gingerne dan gingerol yang terkandung dalam jahe berperan dalam menghambat pertumbuhan bakteri Escheria coli dan Bacillus subtilis. Aktivitas antimikroba jahe juga sangat efektif menghambat pertumbuhan Salmonella thypii (bakteri gram negatif penyebab tipus), Bacillus cereus, dan Staphilococcus aureus (bakteri gram positif penyebab gangguan pencernaan) (Irfan, 2008).

Aktivitas antimikroba jahe terhadap mikroba perusak dan patogen berpotensi mengawetkan, sehingga tidak perlu lagi menambahkan bahan pengawet sintetis. Jahe juga dapat menghambat pertumbuhan Aspergillus, yang dapat memproduksi aflatoksin. Selain itu, jahe juga dapat menghambat Saccharomyces cereviceae dan Mycoderma spp. Antimikroba merupakan senyawa yang mampu menghambat, bahkan membunuh mikrobia dalam konsentrasi tertentu (Radiyati, 1992).

Penelitian ini bertujuan untuk mengetahui jumlah total mikroba susu kedelai (Glycine max) hasil olahan masyarakat Desa Layeni Kecamatan Teon Nila Serua Kabupaten Maluku Tengah dengan penambahan sari jahe merah (zingiber officinale var. rubrum) selama penyimpanan. Diharapkan penelitian dapat menjadi bahan informasi guna pengembangan bidang teknologi pangan tepat guna sekaligus sumber informasi bagi pengusaha susu kedelai untuk meningkatkan kualitas produk susu kedelai yang dihasilkannya. 


\section{METODE PENELITIAN}

\section{Jenis Penelitian}

Penelitian ini merupakan jenis penelitian eksperimen laboratorium, untuk mengetahui jumlah total mikroba susu kedelai hasil olahan masyarakat Desa Layeni Kecamatan Teon Nila Serua Kabupaten Maluku Tengah dengan penambahan sari jahe merah (zingiber officinale var. rubrum) selama penyimpanan. Penelitian ini dilaksanakan di Laboratorium STKIP Gotong Royong Masohi dan dilanjutkan di Laboratorium Balai Perindustrian Ambon pada bulan Mei 2017.

\section{Sampel Penelitian}

Sampel penelitian yang diujikan terdiri dari 4 taraf perlakuan meliputi :

A : Penambahan susu kedelai tanpa sari jahe merah $0 \%$

$\mathrm{B}$ : Penambahan susu kedelai dengan sari jahe merah $0,5 \%$

C : Penambahan susu kedelai dengan sari jahe merah $1 \%$

$\mathrm{D}$ : Penambahan susu kedelai dengan sari jahe merah $1,5 \%$

Yang masing-masing taraf perlakuan selanjutnya disimpan selama 0, 6, 12, 18 dan 24 jam.

\section{Prosedur Penelitian}

Teknik dan prosedur penelitian dilakukan secara bertahap meliputi: proses pembuatan sari jahe merah, proses pengolahan susu kedelai dengan campuran sari jahe merah, pengujian daya simpan susu kedelai dengan penambahan sari jahe merah, serta pengujian total mikroba susu kedelai dengan penambahan sari jahe merah.

\section{Pembuatan Sari Jahe Merah}

Pembuatan sari jahe merah dilakukan dengan cara sebanyak 100g rimpang jahe merah dibersihkan dengan cara dikupas dengan menggunakan pisau hingga cukup bersih, cuci dengan air bersih selanjutnya dihaluskan dengan menggunakan blender. Jahe merah yang sudah diblender selanjutnya diperas dan disaring dengan menggunakan saringan kain yang halus untuk memisahkan sari jahe dari ampasnya.

\section{Proses Pengolahan Susu Kedelai dengan Penambahan Sari Jahe Merah}

Proses pembuatan susu kedelai dengan penambahan sari jahe merah dilakukan dengan aplikasi bahan antara lain 400g kacang kedelai, $400 \mathrm{ml}$ air panas, 100g gula pasir dan 50g garam. Dengan prosedur sebagai berikut : siapkan kedelai yang akan diolah, cuci bersih dengan menggunakan air mengalir, rebus kedelai kurang lebih 15 menit, angkat rebusan kedelai lalu rendam menggunakan air bersih selama kurang lebih 11 jam (supaya lunak dan kulit arinya mengelupas), cuci bersih sambil kelupas kulit yang masih tersisa (tiriskan), blender dengan $400 \mathrm{ml}$ air, tuang kedelai yang sudah diblender ke dalam sebuah wadah, saring untuk memisahkan ampas, masak 
dengan api sedang sambil diaduk hingga mendidih (tambahkan $100 \mathrm{ml}$ sari jahe merah, gula dan garam) selama 15 menit.

\section{Proses Pengujian Jumlah Total Mikroba Susu Kedelai}

1. Timbang secara aseptik sebanyak $25 \mathrm{ml}$ sampel, kemudian masukkan dalam wadah blender steril atau plastik stomacher. Tambahkan $225 \mathrm{ml}$ larutan Butterfield's Phosphat Buffered steril dan diblender selama 1 sampai 2 menit.

2. Dengan menggunakan pipet steril, pindahkan $1 \mathrm{ml}$ sampel di atas, masukkan ke dalam larutan Butterfield's Phosphat Buffered untuk mendapatkan pengenceran 102. Siapkan pengenceran selanjutnya $\left(10^{-3}\right)$ dengan mengambil $1 \mathrm{ml}$ sampel dari pengenceran $10^{-2}$ dengan menggunakan pipet steril dan masukkan ke dalam $9 \mathrm{ml}$ larutan Buffered Phosphat. Dengan cara yang sama lakukan pengenceran selanjutnya $10^{-4}, 10^{-5}, \ldots$, sesuai dengan kebutuhan sampel.

3. Pipet sebanyak $1 \mathrm{ml}$ dari setiap pengenceran di atas dan masukkan ke dalam cawan petri steril serta lakukan secara duplo untuk setiap pengenceran.

4. Tambahkan 12 sampai $15 \mathrm{ml}$ Plate Count Agar yang sudah didinginkan hingga mencapai suhu 44 sampai $46^{\circ} \mathrm{C}$ ke masing-masing cawan yang sudah berisi larutan sampel, supaya larutan sampel dan media PCA tercampur seluruhnya lakukan pemutaran cawan ke depan dan ke belakang. Selanjutnya inkubasi selama 48 jam atau 2 hari pada inkubator suhu $\pm 35^{\circ} \mathrm{C}$.

5. Hitung jumlah koloni 25 sampai 250 dengan penghitung koloni atau "Hand Tally Counter" pada cawan petri.

\section{HASIL DAN PEMBAHASAN}

Hasil penelitian jumlah total mikroba susu kedelai dengan penambahan sari jahe merah (Zingiber officinale var. rubrum) selama penyimpanan secara ringkas dapat dilihat pada tabel dan grafik berikut:

Tabel Hasil Uji Total Mikroba Susu Kedelai dengan Penambahan Sari Jahe Merah

\begin{tabular}{|c|c|c|c|c|c|c|}
\hline \multirow{2}{*}{$\begin{array}{l}\text { Konsentrasi } \\
\text { Ekstrak Jahe }\end{array}$} & \multicolumn{5}{|c|}{ Daya Simpan } & \multirow{2}{*}{ Total } \\
\hline & 0 & 6 & 12 & 18 & 24 & \\
\hline A (Kontrol) & $2,5 \times 10^{7}$ & $6,1 \times 10^{7}$ & $7,1 \times 10^{7}$ & $8,2 \times 10^{7}$ & $9,5 \times 10^{7}$ & $3,3 \times 10^{7}$ \\
\hline B $(0,5 \%)$ & $5,7 \times 10^{7}$ & $2,9 \times 10^{7}$ & $5,0 \times 10^{7}$ & $5,3 \times 10^{7}$ & $6,2 \times 10^{7}$ & $2,5 \times 10^{7}$ \\
\hline C (1\%) & $1,6 \times 10^{6}$ & $3,1 \times 10^{7}$ & $3,8 \times 10^{7}$ & $4,1 \times 10^{7}$ & $4,7 \times 10^{7}$ & $1,5 \times 10^{6}$ \\
\hline $\mathrm{D}(1,5 \%)$ & $3,4 \times 10^{4}$ & $4,3 \times 10^{4}$ & $5,2 \times 10^{6}$ & $8,7 \times 10^{6}$ & $4,7 \times 10^{7}$ & $5,2 \times 10^{5}$ \\
\hline
\end{tabular}

Sumber: Data Penelitian (2017) 


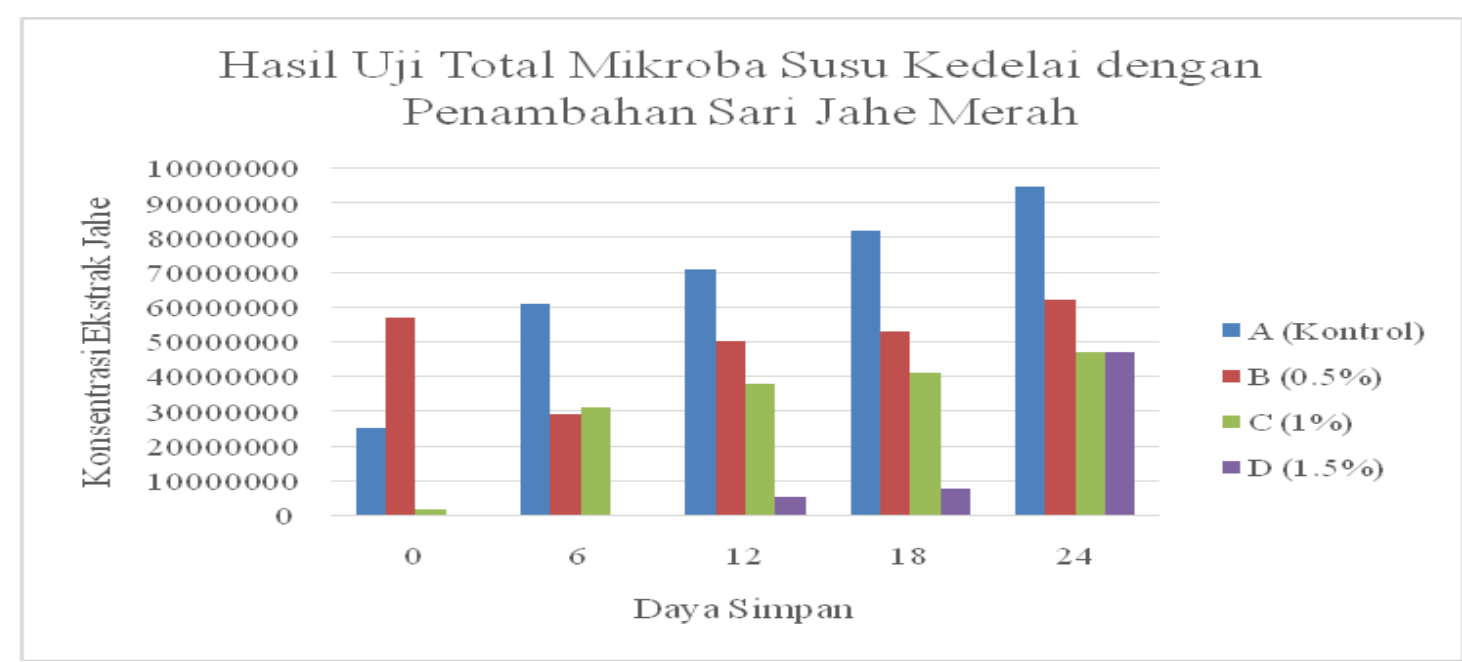

Gambar 1. Hasil Uji Total Mikroba Susu Kedelai dengan Penambahan Sari Jahe Merah

Tabel dan grafik diatas menunjukkan bahwa jumlah total mikroba tertinggi terdapat pada perlakuan konsentrasi jahe merah $0 \%$ atau tanpa jahe merah (A) adalah $3,3 \times 10^{7} \mathrm{koloni} / \mathrm{ml}$. Hal ini dikarenakan susu kedelai tanpa penambahan sari jahe merah tidak memiliki senyawa antimikroba sehingga mikroba yang terdapat pada perlakuan ini mengalami peningkatan secara signifikan. Hasil penelitian menunjukkan bahwa jumlah total mikroba susu kedelai terendah terdapat pada kosentrasi $1,5 \%$ tanpa penyimpanan $(0$ jam $)$ yaitu $\left(3,4 \times 10^{4} \mathrm{koloni} / \mathrm{ml}\right)$ sedangkan jumlah total mikroba tertinggi terdapat pada konsentrasi sari jahe merah $0 \%$ penyimpanan 24 jam yaitu (9,5 x $\left.10^{7} \mathrm{koloni} / \mathrm{ml}\right)$. Menurut Standard Nasional Indonesia (SNI) No.06.87388-2009 persyaratan cemaran mikroba pada produk sari kedelai yaitu mengandung total mikroba maksimal $5 \times 10^{4}$ koloni/ml, maka dapat disimpulkan bahwa penambahan kosentrasi 1,5\% sari jahe merah (Zingiber officinale var. Rubrum) dapat meningkatkan daya simpan susu kedelai selama 6 jam dengan total mikroba 4,3 x10 koloni/ml.

Hal ini menunjukan bahwa semakin tinggi konsentrasi sari jahe merah maka tingkat aktivitas mikroba semakin berkurang. Hal ini sejalan dengan Ma'ruf (2011) menyebutkan bahwa jahe merah terbukti mempunyai aktifitas sebagai antimikroba. Senyawa pada jahe merah dapat mengakibatkan kematian alami mikroba. Senyawa fenol merupakan salah satu kelompok utama bahan antimikroba kimiawi. Hasil penelitian lainpun menunjukkan bahwa bahan aktif jahe (gingerol) mampu menghambat pertumbuhan mikroba. Jahe merupakan rempah-rempah yang memiliki komponen bioaktif yang dapat berfungsi sebagai pengawet alami yang dapat menghambat pertumbuhan atau membunuh mikroba.

Jahe merah sebagai zat antimikroba ditambahkan dalam susu kedelai bertujuan untuk memperpanjang masa simpan karena berfungsi menghambat pertumbuhan mikroba. Hal ini terjadi karena semakin banyak penambahan sari jahe merah maka 
semakin sedikit jumlah mikroba yang akan tumbuh dan semakin lama daya simpan susu kedelai, ini membuktikan bahwa jahe memiliki senyawa antimikroba yang bersifat bakterisidal (membunuh bakteri) dan bakteristatik (menghambat pertumbuhan mikroba (Andarwulan ,2004). Hal ini sesuai dengan pendapat Winarno (1994), bahwa efektifitas dari suatu bahan pengawet anti mikroba ditentukan oleh konsentrasinya dan pada umumnya makin tinggi konsentrasi bahan pengawet yang digunakan maka makin besar pula efektifitasnya.

Terjadinya perubahan-perubahan selama penyimpanan 6, 12, 18 dan 24 jam dapat dipahami, karena menurut Ngantung, $d k k$ (1978) bahwa zat antimikroba yang terdapat dalam sari jahe merah berfungsi hanya menunda kerusakan produk selama penyimpanan tetapi bukan untuk mencegah kerusakan sebab pada akhirnya produk tersebut akan rusak atau mengalami penurunan mutu. Penurunan mutu produk selama penyimpanan dapat diakibatkan oleh serangan mikroba yang berkembang dan bertambah jumlahnya selama penyimpanan oleh pengaruh lingkungan. Dengan demikian, makin singkat waktu distribusi produk dari produsen ke konsumen maka semakin baik mutunya. Akan tetapi daya tahan dan lama masa simpan yang maksimal bagi produk berbeda-beda tergantung dari jenis produk, metode pengawetan dan jenis bahan pengawet serta tingkat konsentrasi yang digunakan. Maka dapat dikatakan bahwa, untuk mendapatkan susu kedelai yang berkualias baik dan tahan lama, sebaiknya diberikan pengawet menurut standart SNI dan diperhatikan masa simpan yang maksimal disertai dengan penggunaan konsentrasi bahan pengawet yang optimal sehingga tidak berakibat buruk dan membahayakan kesehatan bagi konsumen.

\section{KESIMPULAN}

Jumlah total mikroba susu kedelai dengan penambaan sari jahe merah terendah terdapat pada kosentrasi $1,5 \%$ tanpa penyimpanan ( 0 jam) yaitu $3,4 \times 10^{4} \mathrm{koloni} / \mathrm{ml}$ sedangkan jumlah total mikroba tertinggi terdapat pada konsentrasi sari jahe merah $0 \%$ penyimpanan 24 jam yaitu 9,5 x $10^{7} \mathrm{koloni} / \mathrm{ml}$. Menurut Standard Nasional Indonesia (SNI) No.06.8-7388-2009 persyaratan cemaran mikroba pada produk sari kedelai yaitu mengandung total mikroba maksimal $5 \times 10^{4} \mathrm{koloni} / \mathrm{ml}$, maka dapat disimpulkan bahwa penambahan kosentrasi $1,5 \%$ sari jahe merah (Zingiber officinale var. Rubrum) dapat mempertahankan daya simpan susu kedelai selama 6 jam dengan total mikroba 4,3 x $10^{4} \mathrm{koloni} / \mathrm{ml}$.

\section{DAFTAR PUSTAKA}

Astawan, M. 2009. Sehat dengan Hidangan Kacang dan Biji-bijian. Jakarta: Penebar Swadaya.

Badan Standarisasi Nasional, 1995. SNI No. 01-3830-1995, Syarat Mutu Susu Kedelai. Badan Standarisasi Nasional. Jakarta.

Codex Alimentarius Comission, 2004.CAC/RCP 57-2004 : Code Of Hygienic Practice For Milk And Milk Products. Fao And Who, Rome. 


\section{Median Volume 12 Nomor 2 Bulan 2020}

Doi http://doi.org/md.v12i2.561

Ngantung, dkk., 1978. Dasar-Dasar Teknologi Pangan. Departemen Mekanisasi dan Teknologi Fakultas Ilmu Ilmu Pertanian, Universitas Hasanudin, Ujung Pandang.

Radiyati, T. 1992. Pengolahan Kedelai. Subang: BPTTG Puslitbang Fisika Terapan_LIPI.

Resnawati. 2006. Kualitas susu pada berbagai pengolahan dan penyimpanan. Makalah semiloka Nasional Prospek Industri Sapi perah Menuju Perdagangan Bebas 2020. Litbang. 